\title{
REVIEW
}

\section{Yael Feldman}

Glory and Agony:

\section{Isaac's Sacrifice and National Narrative}

\author{
(Stanford: Stanford University Press, 2010), hardcover, xv + 421 pp. \\ Neta Stahl, Johns Hopkins University
}

Yael Feldman's Glory and Agony is a journey into the Israeli psyche and the history of its formation. In one of the most comprehensive and impressive historiographies of Hebrew national culture, Feldman elegantly yet passionately presents a multi-dimensional narrative of the Israeli preoccupation with Genesis 22, the near-sacrifice of Isaac known in Hebrew as the Aqedah (the Binding). Feldman uses this topos in order to analyze the changes in views of national sacrifice in diverse sources including non-fiction, fiction, poetry, drama, and memoir. In many senses her book does even more than that. It contextualizes this national obsession within its religious, philosophical, historical, and artistic frameworks, and by doing so, offers a new and fresh methodology for cultural national historiography. It also makes a contribution to our understanding of the ways that Israelis appropriated Christian symbolism, especially images of Jesus' sacrifice, which they juxtaposed to Isaac's near-sacrifice.

Starting at the beginning and culminating at the very end of the $20^{\text {th }}$ century, the book follows the changes in perceptions of the Aqedah, and specifically the preoccupation with its "heroes," to borrow poet Yehuda Amichai's reference to Abraham's, Isaac's, and God's roles in this story. In his poem "The Real Hero of the Aqedah," Amichai actually anoints the ram as "the real hero," but, as Feldman shows, the question, at least since the second half of the 20th century, was not so much "Who is the hero or the protagonist of the story?", but rather "Who is its sacrifice or victim?" (p. 273). The fact that in modern Hebrew the word qorban means both "sacrifice" and "victim" is only one explanation, as Feldman shows, for this victim-victimizer and sacrificesacrificer discourse.

In the first part of the book, Feldman discusses the roots of the secularization of the biblical Aqedah and the ways it was transformed from a religious text into "a trope for heroic national sacrifice" (p. 34). She shows that though the ideas of martyrdom and sacrifice were central to the ethos of early $20^{\text {th }}$-century Israeli political writing, the Aqedah itself was not. Feldman traces this rhetorical shift from martyrdom to Aqedah, analyzing its literary, cultural, theological, and historical meanings. For the writers of the first half of the $20^{\text {th }}$ century, the sacrifice was Isaac's, not Abraham's, and it was perceived as a model of a noble way of giving of or sacrificing oneself. This perception was influenced by post-biblical, including Christian, perceptions of sacrifice, which allowed for a richer psychological portrait of Isaac. Feldman argues that this kind of understanding of Isaac was related to the common use of Christian symbolism in Hebrew literature in Palestine during the 1920s and 1930s.

Indeed, the figure of Jesus plays a central role in this literature, representing a "positive spiritual model," as Feldman puts it (p. 111). She offers two different examples for the adoption of both Jesus and Isaac in the Aqedah. The first example is that of the poet Uri Zvi Greenberg. In 
Greenberg's 1920s poetry, the figure of Jesus functions as a symbol of universal and Jewish suffering, and the Aqedah is hardly mentioned. In the aftermath of the Holocaust, Greenberg invokes the Aqedah not so much as an emblem of victimhood, but rather as a symbol of sacrificial devotion. The second example is that of Avraham Shlonsky, whose poetry was influenced by the secularized religious symbolism of the Russian revolution. Here the figure of Jesus plays a different role, adopted as a "metaphor for secular, even socialist, messianism" (p. 113). Interestingly, Shlonsky rewrote the Aqedah in his poetry, using Christian symbolism for the Zionist pioneers' sacrifice. Shifting from the martyrological figures of previous generations, and using the trope of the mythological "holy family" of Christianity as a bridge to the more personal images of the Aqedah, Shlonsky and his peers shifted the collective images of martyrdom to personal ones.

It is this modernist individuality and desire for a myth of the individual rather than the collective that, according to Feldman, shaped Israelis' discourse and their unique perceptions of the Aqedah. More specifically, it was "Freud's morbid emphasis on the aggression animating human psychology and family dynamics" that became a common theme in the re-writing of the biblical narrative (p. 116). In the second part of the book, Feldman deals with the "transition from glory to agony and then to agon" between 1945 and 1995 (p. 43). She argues that in each decade a new generation of Israeli writers faced different challenges, including war, and as a result changed the narrative of the Aqedah and the conception of its sacrifice/s and victim/s.

Three major themes dominated the re-writing of the Aqedah in the 1940s-50s according to Feldman: a new look at the Zionist pioneering enterprise, the Holocaust, and the 1948 war. The surprising aspect of the return to the biblical story is authors use the very same trope in constructing two opposing experiences, that of a willing sacrifice and of a tragic victim. In the 1960s, there was a turn to an agonistic revision of the Aqedah, which developed into a psycho-political debate. This generation read the story of Isaac through the post-biblical rewriting of the Aqedah as a Freudian narrative, turning the binding into sacrifice and even murder. This "un-glorified aqdeah" was a sort of synthesis of the biblical-Jewish and the Greek-Oedipal models (p. 194). The "Isaac generation" of 1967-1973 identified with the son "only to reject his self-immolation," protesting against the harmonic inter-generational relationship between father and son of most traditional depictions of the story (p. 217). The Yom Kippur War in 1973 brought an even sharper revision of the story that again looked at both the lamenting parents and their sacrificed sons, in particular, the different Isaacs / Ishmaels that were slaughtered. This "theology of sacrifice," as Feldman calls it, becomes an object of struggle for Israeli writers throughout these decades (p. 209).

Christian images influence many of these writers. The image of Jesus as lamb is both present and rejected in many of these works on the Aqedah. The last "Isaac" in the book (before the afterword) is the assassinated Israeli Prime Minister Yitzhak Rabin (1922-1995). Feldman asserts that Rabin, despite his name (Yitzhak is Hebrew for Isaac) "was no Isaac," but rather an "Abrahamic paternal figure," and that the assassination by an Israeli Jew was a "violently oedipal breach" (p. 309). But we should note that in the eyes of the shocked Israelis, the dead father was perceived as the sacrificed, or perhaps crucified, son-lamb, at least judging from the fact that the music the Israeli Broadcasting Authority chose to accompany the broadcast of his memorial was none other than Johann Sebastian Bach's Matthews-Passion.

Feldman's book is an outstanding achievement that is likely to engage scholars and readers for many years to come. 